\title{
Resveratrol Attenuates Benzo(a)pyrene-Induced Dysfunctions, Oxidative Stress and Apoptosis in Pancreatic Beta-Cells
}

\author{
Sefa Çelik¹, Bariş Baysal'1, Serkan Şen² \\ ${ }^{1}$ Department of Medical Biochemistry, Faculty of Medicine, Afyonkarahisar Health Sciences University, Afyonkarahisar, Turkey \\ ${ }^{2}$ Atatürk Vocational School of Health Services, Afyonkarahisar Health Sciences University, Afyonkarahisar, Turkey \\ Email: sefa_celik@hotmail.com
}

How to cite this paper: Çelik, S., Baysal, B. and Şen, S. (2019) Resveratrol Attenuates Benzo(a)pyrene-Induced Dysfunctions, Oxidative Stress and Apoptosis in Pancreatic Beta-Cells. Advances in Bioscience and Biotechnology, 10, 389-404.

https://doi.org/10.4236/abb.2019.1011029

Received: October 5, 2019

Accepted: November 18, 2019

Published: November 21, 2019

Copyright $\odot 2019$ by author(s) and Scientific Research Publishing Inc. This work is licensed under the Creative Commons Attribution International License (CC BY 4.0).

http://creativecommons.org/licenses/by/4.0/

\begin{abstract}
Background: Diabetes mellitus is one of the major health problems for people all over the world today. According to international diabetes federation reports, diabetes affects 382 million people worldwide. Environmental pollutants have deleterious effects on glucose metabolism and cause insulin resistance. We aimed to investigate the effects of the environmental pollutants benzo(a)pyrene, and the therapeutic potential of resveratrol. Methods: $20 \mu \mathrm{M}$ of benzo(a)pyrene was administered after $48 \mathrm{~h}$ of resveratrol $(80 \mu \mathrm{M})$ application for $24 \mathrm{~h}$ in INS-1 (832/13) insulinoma cells. The cells were treated with $20 \mu \mathrm{M}$ benzo(a)pyrene for 24 hours after 48 hours initial preconditions with $10 \mu \mathrm{M}$ resveratrol. Oxidative stress status, insulin secretion and apoptosis were analyzed by molecular techniques. Results: Though resveratrol increased the antioxidant status which was decreased by benzo(a)pyrene, interestingly, it increased the oxidative status. Resveratrol increased benzo(a)pyrenedepleted reduced glutathione levels to the control level. The mRNA expression levels of beta-cell functions associated with genes insulin-1, insulin-2 and sirtuin-1 were upregulated by resveratrol. Resveratrol treatment elevated the insulin concentration of culture medium, and the mRNA expression of forkhead box protein-1 gene. Resveratrol upregulated benzo(a)pyrene-downregulated p53 gene expression. On the other hand, benzo(a)pyrene-downregulated mRNA expression of B-cell lymphoma-2 was induced by resveratrol treatment. Conclusion: The data showed that resveratrol could reverse the oxidative alterations, functional impairments and the carcinogenetic effects of benzo(a)pyrene in pancreas beta-cells.
\end{abstract}

\section{Keywords}

Benzo(a)pyrene, INS-1 (832/13) Insulinoma Cell, Insulin, Apoptosis, 
Oxidative Stress, Resveratrol

\section{Introduction}

Diabetes mellitus (DM) is characterized by exclusively or partially deficiency of insulin released from the pancreas. Type $2 \mathrm{DM}$ (T2DM) is closely related with insulin resistance and is life threatening as significant public health problem in adults, children and adolescents [1] [2] [3]. Diabetes ranks seventh in the causes of death. In the early stages of T2DM, the beta cells produce excessive amounts of insulin to ensure the continuation of normal blood glucose levels. However, beta cells can not cope with mitochondrial dysfunction, resulting in endoplasmic reticulum stress and apoptosis [4]. Consequently, a reduction occurs in the beta cell mass [5].

The oxidative stress may develop due to the production of reactive oxygen species (ROS) in high levels and/or lack of antioxidant defense system [6]. The activities of antioxidant enzymes are increased in diabetes. It is thought that increases of hydrogen peroxide and superoxide by the events including non-enzymatic glycosylation and auto-oxidation of glucose are the basis of this phenomenon [7]. Significant decreases in plasma reduced glutathione (GSH) levels occur in diabetes [8]. The GSH is the most important bio-molecule in defense against chemicals. It also acts as a free radical scavenger and can repair cell damage caused by radicals [9].

The essential factors for the progression of the T2DM are obesity and insulin resistance. However, this results in inadequate insulin secretion from beta cells to compensate for insulin deficiency. In either case, it is regarded as the main pathway of the beta cell death, apoptosis. There are many potentially effective stimulants in the apoptosis of the beta cell. These are Fas ligand and Fas receptors as death receptors, perforins, cytokines [10] [11], ROS [12], reactive nitrogen species [13], alkylating agents [14], ceramide [15]; lack of growth factors [16].

It has been hypothesized by Longnecker and Daniels [17] that chemical contaminants may play an important role in the etiology of T2DM. This hypothesis was supported by epidemiological studies; this is an indication that the increase in insulin resistance or incidence of T2DM is a consequence of exposure to high levels of arsenic, organochlorine contaminants and air pollution [18] [19] [20] [21].

Pollution has harmfull effects on human health directly. Approximately $40 \%$ of human deaths in the world depend on environmental pollution. Even people who have never smoked in their lifetime are suffering from respiratory diseases such as lung cancer due to air pollution. Polluted waters cause many diseases. More than 1.2 million people in the world cannot find clean water for their lives. Contaminated soil carries chemicals and numerous toxins. Benzo(a)pyrene $[\mathrm{B}(\mathrm{a}) \mathrm{P}]$ is a compound with a pentacyclic polycyclic aromatic hydrocarbon 
structure. The most important source of atmospheric $\mathrm{B}(\mathrm{a}) \mathrm{P}$ is wood burning. It is also found in coal tar, in automobile exhaust fumes (especially in diesel engines) and in all fumes from organic materials and grilled food burning [22]. The metabolites of $\mathrm{B}(\mathrm{a}) \mathrm{P}$ are carcinogenic and cause DNA degradation. For example, Benzo(a)pyran-8-diol-9,10-epoxide forms further DNA products [23] [24].

Resveratrol (RES) is a natural phytoalex produced by many fruits and plants, including grapes. It prevents DNA damage and lipid peroxidation in cell membranes. Various research studies [25] [26] [27] have indicated that it is necessary to carry out further studies on how RES can be used in cancer treatment. Resveratrol activates sirtuin (Sirt)-1 [28] which plays an important role in many different physiological events such as cell cycle regulation, metabolism and inflammation [29]. Previous studies have demonstrated that Sirt-1 has a positive regulatory role in insulin secretion and the persistence of beta cell function [30] [31] [32].

However, to our knowledge, there is no previous report on the direct effect of environmental pollutant $\mathrm{B}(\mathrm{a}) \mathrm{P}$ on insulin levels produced by pancreatic beta cells. Therefore, the present study was designed to evaluate the possible effects of RES on oxidative stress, diysfunction and apoptosis in the pancreatic beta cells exposed to $\mathrm{B}(\mathrm{a}) \mathrm{P}$ in vitro.

\section{Materials and Methods}

\subsection{Materials}

All chemicals except resveratrol (Cayman Chemical, Tallin, Estonia) were purchased from Sigma-Aldrich (Germany). INS1-E pancreatic cell line was obtained from Lisa Poppe (Duke University Medical Center, USA).

\subsection{Cell Culture and Treatments}

Rat panceatic INS-1 (832/13) cell line was cultured in RPMI 1640 supplemented with $10 \% \mathrm{FBS}, 100$ units $/ \mathrm{ml}$ penicillin and $100 \mu \mathrm{g} / \mathrm{ml}$ streptomycin, $1 \mathrm{mM}$ sodium pyruvate, $5 \mathrm{mM}$ glutamine, $50 \mu \mathrm{M}$ 2-mercaptoethanol and $10 \mathrm{mM}$ HEPES buffer. Cells were incubated at $37^{\circ} \mathrm{C}$ in a humidified atmosphere (95\% air, $5 \%$ $\mathrm{CO}_{2}$ ). INS-1 cells were seeded at a density of $2.1 \times 10^{6} \mathrm{cells} / \mathrm{ml}$ in a $75-\mathrm{cm}^{2}$ culture flask and grown for 2 - 3 days before use.

\subsection{Experimental Groups}

INS-1 $\beta$-cells were divided into four groups: control group, resveratrol administrated group, benzo(a)pyrene treated group, and benzo(a)pyrene treated followed by resveratrol administrated group. Resveratrol was administered in an amount of $10 \mu \mathrm{M}$ for $48 \mathrm{~h}$ in RES and RES $+\mathrm{B}(\mathrm{a}) \mathrm{P}$ goups [33]. After first incubation, 20 $\mu \mathrm{M} B(\mathrm{a}) \mathrm{P}[34$ ] was added into the flasks in $\mathrm{B}(\mathrm{a}) \mathrm{P}$ and RES $+\mathrm{B}(\mathrm{a}) \mathrm{P}$ groups, and this second incubation was carried out for $24 \mathrm{~h}$. After last incubation, the cells were separated from medium and used for biochemical analysis. Each assay was performed in triplicate and repeated three times. 


\subsection{Protein Analysis}

The medium was removed, and the cells were harvested by trypsin-EDTA treatment and washed twice with PBS. The harvested cells were lysed in lysis buffer. The lysates were centrifuged at $12.000 \mathrm{~g}\left(4^{\circ} \mathrm{C}, 10 \mathrm{~min}\right)$. The protein concentrations were determined in supernatants by Bradford method [35].

\subsection{Glucose Stimulated Insulin Secretion Analysis}

After incubating with resveratrol and $\mathrm{B}(\mathrm{a}) \mathrm{P}$, the cells were washed in KrebsRinger bicarbonate (KRB) solution containing $2.8 \mathrm{mM}$ glucose for $1 \mathrm{~h}$, with subsequent incubation in KRB solution, containing $2.8 \mathrm{mM}$ glucose for $30 \mathrm{~min}$ at $37^{\circ} \mathrm{C}$. At the end of the experiment, secreted insulin levels were quantified in the medium samples by the Rat/Mouse Insulin ELISA kit (EZRMI-13K, Merck Millipore, Merck Darmstadt, Germany).

\subsection{Measurements for Oxidative Stress-Related Parameters}

The total antioxidant status (TAS) of the cell lysate was determined by the test kit from Rel Assay Diagnostics (Gaziantep, Turkey). This colorimetric method based on the bleaching of color characteristics of a more stable ABTS

[2,2'-azino-bis(3-ethylbenzothiazoline-6-sulphonic acid)] radical cation by antioxidants [36].

The total oxidant status (TOS) levels were determined by the test kit from Rel Assay Diagnostics (Gaziantep, Turkey) using a novel automated method, which was developed by Erel [37], in the cell lysates. In this method, oxidants presented in the sample oxidized the ferrous ion-o-dianisidine complex to ferric ion. The ferric ion produced a colored complex with xylenol orange in an acidic medium. The color intensity was measured spectrophotometrically at $530 \mathrm{~nm}$ wavelength. The results were calibrated with hydrogen peroxide and expressed as $\mu \mathrm{mol} \mathrm{H}_{2} \mathrm{O}_{2}$ equiv./mg prot).

The Oxidative Stress Index (OSI), which is an indicator of the degree of oxidative stress, was calculated according to the formula: OSI $=$ TOS $(\mu \mathrm{mol} / \mathrm{mg}$ prot)/(TAS (mmolTroloxEquiv/L) $\times 100$ [38].

The Griess reaction was used for determining the NO levels in the cell lysates [39]. The results were expressed as $\mu \mathrm{mol} / \mathrm{mg}$ protein.

The GSH level of samples was determined by spectrophotometer at $412 \mathrm{~nm}$ after the reaction between sulfhydryl groups present in supernatant and DTNB (5,5'-2-dithiobis nitrobenzoic acid) [40]. The results of the analysis were expressed as $\mu \mathrm{mol} / \mathrm{mg}$ protein.

\subsection{Total RNA Isolation and Real Time PCR Analysis}

The cells were seeded in $25-\mathrm{cm}^{2}$ culture flasks and grown for $1-2$ days before use. Cells were collected and washed with PBS after completion of incubations given above. Total RNA was isolated by RNAeasy kit according to manufacturer's instructions (Qiagen, Valencia, CA). cDNA was generated with a First Strand 
cDNA Synthesis kit according to manufacturer's instructions (Thermo Scientific, Waltham, MA USA). Briefly, $1 \mu \mathrm{g}$ of total RNA was used as template in RT reaction, which was carried out with RevertAidTM H(-) M-MuLV Reverse Transcriptase (MBI Fermentas) following instructions provided by the manufacturers. RNA was mixed with $10 \mu \mathrm{M}$ primer (oligodT, random hexanucleotides or specific primers), incubated $5 \mathrm{~min}$ at $65^{\circ} \mathrm{C}$, and kept on ice for $2 \mathrm{~min}$ to allow hybridization. Then, RT reaction Mix (buffer 5X, dNTPs mix $10 \mathrm{mM}$ each one, RNase inhibitor RNaseOUT (40 U/ $\mu$ l) (Invitrogen)) and Reverse Transcriptase were added following manufacturer instructions. After $60 \mathrm{~min}$ incubation at $42^{\circ} \mathrm{C}(\mathrm{M}-\mathrm{MuLV})$ the $\mathrm{RT}$ enzyme was heat inactivated at $70^{\circ} \mathrm{C}$ for 5 min.

The real-time PCR reactions were performed using a Strategene Mx3005P QPCR system (Agilent, CA, USA). The reaction mix contained $12.5 \mu \mathrm{l}$ of Maxima SYBR Green qPCR Master Mix (2x), no ROX (Thermo Scientifics, Massachusetts, USA), $400 \mathrm{nM}$ of each primer, $2 \mu \mathrm{l}$ of cDNA and nuclease-free water to reach a final volume of $25 \mu$. The thermal cycling conditions comprised an initial denaturation step of $5 \mathrm{~min}$ at $95^{\circ} \mathrm{C}$ and $35-40$ amplification cycles which included denaturation at $95^{\circ} \mathrm{C}$ for $30 \mathrm{~s}$ and annealing at $54^{\circ} \mathrm{C}-70^{\circ} \mathrm{C}$ for $60 \mathrm{~s}$ (Table 1). A melt curve analysis was performed after the last cycle, in order to investigate the specificity of the amplicon and the presence of reaction artefacts such as primer dimer, using a temperature gradient from $60^{\circ} \mathrm{C}$ to $100^{\circ} \mathrm{C}$ and a ramp speed of $0.5^{\circ} \mathrm{C} \cdot \mathrm{s}^{-1}$ (for $10 \mathrm{~s}$ ) and continuous fluorescence measurement. Expression levels of the target genes were normalized to the housekeeping gene GAPDH. Gene expression values were then calculated based on the $\Delta \Delta \mathrm{Ct}$ method using the equation: $\mathrm{RQ}=2^{-\Delta \Delta C t}[41]$. The primer sequences used in PCR reactions and PCR conditions are described in Table 1. Each assay was performed in triplicate and repeated three times.

Table 1. Oligonucleotide primer sequences and PCR programs.

\begin{tabular}{|c|c|c|c|}
\hline Transcripts & Primer Sequences & PCR Programs & Cycles \\
\hline p53 & $\begin{array}{l}\text { F-5'CGGAGGTCGTGAGACGCTG'3 } \\
\text { R-5'CACATGTACTTGTAGTGGATGGTGG'3 }\end{array}$ & $94^{\circ} \mathrm{C}-1 \mathrm{~m} / 59^{\circ} \mathrm{C}-1 \mathrm{~m} / 72^{\circ} \mathrm{C}-1 \mathrm{~m}$ & 40 \\
\hline Foxo1 & $\begin{array}{l}\text { F-5'GTGAACACCATGCCTCACAC'3 } \\
\text { R-5'CACAGTCCAAGCGCTCAATA'3 }\end{array}$ & $95^{\circ} \mathrm{C}-15 \mathrm{~s} / 60^{\circ} \mathrm{C}-1 \mathrm{~m} / 72^{\circ} \mathrm{C}-1 \mathrm{~m}$ & 40 \\
\hline Ins-1 & $\begin{array}{l}\text { F-5'CCTGCTCGTCCTCTGGGAGCCCAAG'3 } \\
\text { R-5'CTCCAGTGCCAAGGTCTGAAGATCC’3 }\end{array}$ & $94^{\circ} \mathrm{C}-1 \mathrm{~m} / 68^{\circ} \mathrm{C}-1 \mathrm{~m} / 72^{\circ} \mathrm{C}-1 \mathrm{~m}$ & 35 \\
\hline Ins-2 & $\begin{array}{l}\text { F-5'CCTGCTCATCCTCTGGGAGCCCCGC'3 } \\
\text { R-5'CTCCAGTGCCAAGGTCTGAAGGTCA'3 }\end{array}$ & $94^{\circ} \mathrm{C}-1 \mathrm{~m} / 70^{\circ} \mathrm{C}-1 \mathrm{~m} / 72^{\circ} \mathrm{C}-1 \mathrm{~m}$ & 40 \\
\hline Sirt-1 & $\begin{array}{l}\text { F-5'AGGGAACCTCTGCCTCATCTAC'3 } \\
\text { R-5'GGCATACTCGCCACCTAACCT'3 }\end{array}$ & $94^{\circ} \mathrm{C}-1 \mathrm{~m} / 60^{\circ} \mathrm{C}-1 \mathrm{~m} / 72^{\circ} \mathrm{C}-1 \mathrm{~m}$ & 35 \\
\hline Bcl-2 & $\begin{array}{l}\text { F-5'CAGCTGCACCTGACGCCCTT'3 } \\
\text { R-5'CCCAGCCTCCGTTATTCTGGA'3 }\end{array}$ & $94^{\circ} \mathrm{C}-1 \mathrm{dk} / 58^{\circ}-1 \mathrm{dk} / 72^{\circ} \mathrm{C}-1 \mathrm{dk}$ & 40 \\
\hline GAPDH & $\begin{array}{l}\text { F-5'GTCGTGGAGTCTACTGGCGTC'3 } \\
\text { R-5'GATGACCCTTTTGGCACCACC’3 }\end{array}$ & $94^{\circ} \mathrm{C}-1 \mathrm{~m} / 54^{\circ} \mathrm{C}-1 \mathrm{~m} / 72^{\circ} \mathrm{C}-1 \mathrm{~m}$ & 35 \\
\hline
\end{tabular}

p53, Tumor protein 53; Foxo-1, Forkhead box protein O1; Ins-1, Insulin-1; Ins-2, Insulin-2; Sirt-1, Sirtuin-1; Bcl-2, B-cell lymphoma-2; GAPDH, Glucose-6-phosphate dehydrogenase. 


\subsection{Statistical Analysis}

Since normal distribution was not observed Kruskal Wallis test was used followed by the Conover-Iman test. $\mathrm{P}<0.05$ was considered as statistically significant between the groups. The results were expressed as mean \pm standard deviation. Data were analyzed with the Statistical Package for the Social Sciences (SPSS) version 20.0 for Windows.

\section{Results}

The oxidative stress-related parameters such as NO, TAS, TOS, GSH and OSI are outlined in Table 2 . Interestingly, resveratrol pretreatment significantly $(\mathrm{p}<$ $0.05)$ increased NO production in RES $+\mathrm{B}(\mathrm{a}) \mathrm{P}$ group compared to $\mathrm{B}(\mathrm{a}) \mathrm{P}$-treated cells. Resveratrol significantly $(\mathrm{p}<0.05)$ increased the TAS in both RES treated groups. On the other hand, B $(a) P(p<0.05)$ decreased the TAS level significantly in $\mathrm{B}(\mathrm{a}) \mathrm{P}$ group compared to the CTRL group. These results demonstrated that resveratrol supported the cellular antioxidant defense against $\mathrm{B}(\mathrm{a}) \mathrm{P}$-induced oxidative events. In OSI levels, there was no significant difference between the $\mathrm{RES}+\mathrm{B}(\mathrm{a}) \mathrm{P}$ and $\mathrm{B}(\mathrm{a}) \mathrm{P}$ groups. The GSH levels were significantly $(\mathrm{p}<0.05)$ increased both in the RES group and RES-B(a)P group in comparison with the control and $\mathrm{B}(\mathrm{a}) \mathrm{P}$ group, respectively.

Resveratrol pretreatment increased insulin production significantly $(\mathrm{p}<0.05)$ in RES and RES + B(a)P groups compared to the CTRL and $\mathrm{B}(\mathrm{a}) \mathrm{P}$ groups, respectively (Table 3). Comparison of mRNA expression levels of genes in INS1-E beta cells is presented in Figure 1. Resveratrol upregulated the FoxO1, a gene related with cell proliferation, by approximately 1.43 -fold in RES group in comparison with the control group. The similar upregulation (1.23-fold) of FoxO1 was seen in the $\mathrm{B}(\mathrm{a}) \mathrm{P}$ group too. On the other hand, resveratrol increased the FoxO1 mRNA expression by 1.23 -fold in the RES $+\mathrm{B}(\mathrm{a}) \mathrm{P}$ group compared to the $\mathrm{B}(\mathrm{a}) \mathrm{P}$ group (Figure 1). mRNA expression level of Sirt-1, that has an effective role in the glucose-mediated insulin synthesis, was upregulated by resveratrol in all resveratrol treated groups. This increasing was occurred in the RES + $\mathrm{B}(\mathrm{a}) \mathrm{P}$ group compared to the $\mathrm{B}(\mathrm{a}) \mathrm{P}$ group (Figure 1 ). In our study, $\mathrm{B}(\mathrm{a}) \mathrm{P}$ treatment suppressed the mRNA expression of ins-1 gene by 1.70 -fold in the $\mathrm{B}(\mathrm{a}) \mathrm{P}$ group compared to the control. The suppression of ins-2 gene expression was 2.17-fold in the same group. These results demonstrate that B(a)P significantly reduces the expression of insulin-encoding genes in this study. On the other hand, resveratrol increased the expression of these two genes in all groups treated with resveratrol (Figure 1).

The expression of p53 mRNA was 1.40 -fold reduced by the $\mathrm{B}(\mathrm{a}) \mathrm{P}$ application in group $\mathrm{B}(\mathrm{a}) \mathrm{P}$ compared to the control grou $\mathrm{p}$. On the other hand, an increase of 1.60-fold was detected in the $\mathrm{B}(\mathrm{a}) \mathrm{P}+\mathrm{RES}$ group in comparison with the group which was administrated only with banzo(a)pyrene (Figure 1 ).

The antiapoptotic gene BcL-2 was downregulated by 1.15 -fold in the $\mathrm{B}(\mathrm{a}) \mathrm{P}$ group in comparison with the control group, while resveratrol increased the ex- 
pression of this gene by 1.20 -fold in $\mathrm{B}(\mathrm{a}) \mathrm{P}+$ RES group comparison with $\mathrm{B}(\mathrm{a}) \mathrm{P}$ group (Figure 1).

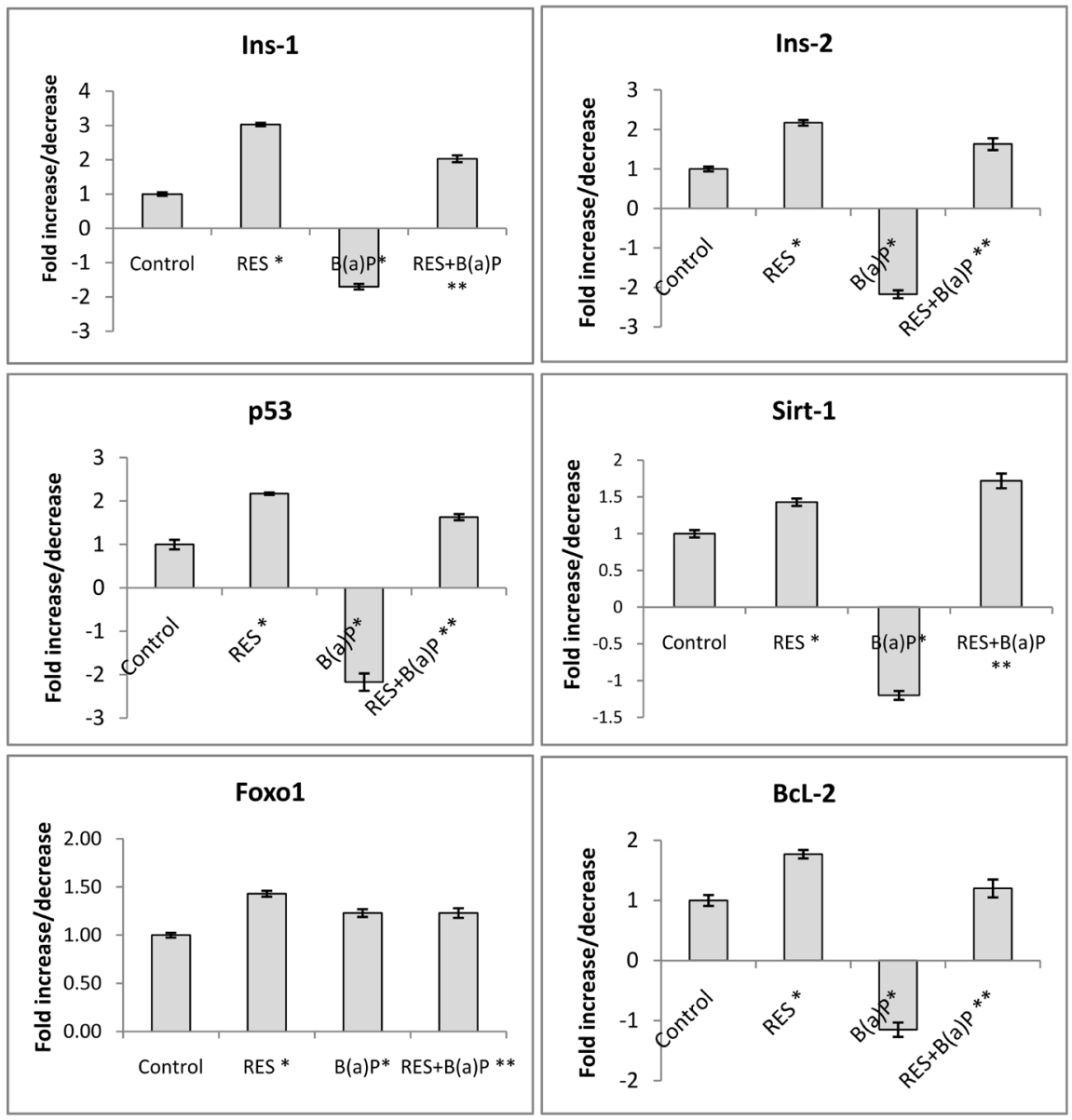

Figure 1. mRNA expression levels of various genes related with proliferation, apoptosis and acticity of beta cell. Foxo-1, Forkhead box protein O1; Sirt-1, Sirtuin-1; Ins-1, Insulin-1; Ins-2, Insulin-2; p53, Tumor protein53; Bcl-2, B-cell lymphoma-2. *: Compared with control group, ${ }^{* *}$ : Compared with $\mathrm{B}(\mathrm{a}) \mathrm{P}$ group.

Table 2. Effect of resveratrol on the levels of NO, TAS, TOS, OSI and GSH in cell lysates.

\begin{tabular}{cccccc}
\hline \multirow{5}{*}{ Groups } & \begin{tabular}{c} 
NO \\
\cline { 2 - 6 }
\end{tabular} & $\begin{array}{c}\text { TAS } \\
(\mu \mathrm{mol} / \mathrm{g} \text { prot }) \\
\left(\mu \text { mol } \mathrm{O}_{2}\right. \\
\text { Equiv/mg prot })\end{array}$ & $\begin{array}{c}\text { TOS } \\
\left(\mu \mathrm{mol} \mathrm{H} \mathrm{O}_{2}\right. \\
\text { Equiv/mg prot })\end{array}$ & OSI & $\begin{array}{c}\text { GSH } \\
(\mu \mathrm{mol} / \mathrm{mg} \text { prot })\end{array}$ \\
\hline Control & $10.78(0.53)^{\mathrm{a}}$ & $5.48(0.83)^{\mathrm{a}}$ & $1.26(0.11)^{\mathrm{a}}$ & $23.39(3.27)^{\mathrm{a}}$ & $5.80(0.63)^{\mathrm{a}}$ \\
RES & $15.50(1.20)^{\mathrm{bc}}$ & $8.36(1.09)^{\mathrm{b}}$ & $2.85(0.40)^{\mathrm{b}}$ & $34.40(6.23)^{\mathrm{b}}$ & $9.57(0.99)^{\mathrm{b}}$ \\
B(a)P & $12.30(0.90)^{\mathrm{a}}$ & $3.04(1.35)^{\mathrm{a}}$ & $1.09(0.36)^{\mathrm{a}}$ & $13.60(3.30)^{\mathrm{c}}$ & $3.77(0.28)^{\mathrm{c}}$ \\
RES + B(a)P & $17.42(1.76)^{\mathrm{c}}$ & $17.05(1.53)^{\mathrm{c}}$ & $2.88(0.46)^{\mathrm{c}}$ & $16.95(2.01)^{\mathrm{c}}$ & $5.64(1.50)^{\mathrm{a}}$ \\
\hline
\end{tabular}

a.b,c: The mean values in a different row are significantly different $(\mathrm{p}<0.05)$. RES: Resveratrol, B(a)P: Benzo(a)pyrene, NO: Nitric oxide, TAS: Total Antioxidant Status, TOS: Total Oxidant Status, OSI: Oxidative Stress Index, GSH: Reduced Glutathione. 
Table 3. Effect of resveratrol on secreted insulin levels.

\begin{tabular}{cccc}
\hline Groups & $\mathbf{n}$ & $\begin{array}{c}\text { Insulin (ng/ml) } \\
\text { Mean (SD) }\end{array}$ & P-value $^{\#}$ \\
\hline Control & 3 & $0.49(0.05)^{\mathrm{a}}$ & \\
RES & 3 & $0.75(0.09)^{\mathrm{bc}}$ & $<0.05$ \\
B(a)P & 3 & $0.60(0.01)^{\mathrm{b}}$ & $<0.05$ \\
RES + B(a)P & 3 & $0.99(0.22)^{\mathrm{c}}$ & $<0.05$ \\
\hline
\end{tabular}

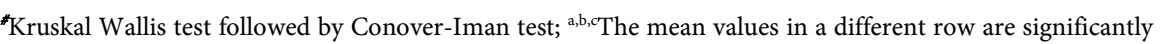
different $(\mathrm{p}<0.05)$. RES: Resveratrol, B(a)P: Benzo(a)pyrene.

\section{Discussion}

Benzo(a)pyrene is known to occur after several combustion reactions [42]. It has been revealed that the air pollution was closely related to diabetes [43].

The $\mathrm{B}(\mathrm{a}) \mathrm{P}$ metabolism causes overexpression of ROS, which are effective in cancer development, by acting as a second messenger for certain cytokines and growth factors in cells [44]. It was reported that ROS could initiate the peroxidation of lipids [45].

It is well known that GSH protects the cells against oxidative damage via its thiol groups [46]. It was reported that the $\mathrm{B}(\mathrm{a}) \mathrm{P}$ application significantly reduced the levels of GSH [47]. Similarly, the level of GSH was reduced by B(a)P in our study. This could be explained by the excessive use of GSH in the process of detoxifying of peroxide radicals that were generated by lipid peroxidation. Likewise, this result was supported by the reducing effects of $\mathrm{B}(\mathrm{a}) \mathrm{P}$ on the TAS in beta cells.

A research study has reported that resveratrol causes an increase in GSH levels in the protective role against oxidative injury [48]. In our study, increase in GSH levels was detected by resveratrol treatment in both RES and $\mathrm{B}(\mathrm{a}) \mathrm{P}+\mathrm{RES}$ groups compared to the control and $\mathrm{B}(\mathrm{a}) \mathrm{P}$ groups, respectively. In addition, it has been reported that resveratrol acts as an antioxidant function such as superoxide dismutase (SOD) and glutathione peroxidase (GPx) [49]. This effect of resveratrol is based on its ability to protect the cell membranes against oxidative damage [50]. Resveratrol is known to have potent antioxidant properties and protective capacity against harmful effects induced by lipid peroxidation [51] [52]. Interestingly, there are some studies showing that resveratrol increases iNOS expression and NO production [53] [54]. Consistent with the literature, the level of NO was increased by resveratrol treatments in this study. This effect may be related to the activation of iNOS.

Resveratrol has been reported to reduce blood sugar and triglyceride levels, and also insulinemia in rats [55]. In consistent with previous studies, RES improved the insulin levels in this study. This effect of RES on insulin secretion could be related to the increased expression of Sirt-1 gene. Kong et al. [56] reported that RES improved glycemic control and insulin levels which was reduced in rats fed with high-fat diets for eight weeks period [56]. From these re- 
sults, researchers have concluded that RES increased the expression of Sirt-1 gene. The results obtained in our study support the literature data.

In a study used Zucker diabetic rats, Sirt-1 gene activator improved the homeostasis of glucose and positively affected the sensitivity of insulin in fat, liver and muscle tissues. It was stated in the same study that the activation of Sirt-1 in the treatment of age-related disease and T2DM was a promising new treatment strategy [57].

It was previously demonstrated that RES increasesd Sirt-1 gene expression in human endothelial cell line EA.HY926 [58]. The same investigators suggested that the anti-inflammatory effect of RES could be achieved with Sirt- 1 and AMP-activated kinase (AMPK). In our study, RES increased the mRNA expression level by 1.34 -fold in the RES group compared to the control, and by 1.72 -fold in the $\mathrm{B}(\mathrm{a}) \mathrm{P}+$ RES group compared to the $\mathrm{B}(\mathrm{a}) \mathrm{P}$ group. In this context, it is suggested that the underlying mechanism in action of RES on GSH regulation due to upregulation of Sirt-1 gene expression as described before. Sirt- 1 accelerates the detoxification of ROS by upregulating cellular antioxidant enzymes, including SOD-1, catalase, GPx-1, and thioredoxin-1. GPx-1 regulates cellular oxidant status directly through elimination of hydroperoxides and via oxidation of GSH, the major low-molecular-weight thiol in cells [59] [60]. Thus, our findings suggest that Sirt-1 was upregulated by RES coordinately might increase GSH and GPx necessary for hydrogen peroxide reduction.

Alternatively, resveratrol may directly increase the level of glutathione with antioxidant effect. Resveratrol has been well known for its possible antioxidant role and protective effects against oxidant damage [61].

In the present study, we tested the ability of RES to attenuate the $\mathrm{B}(\mathrm{a}) \mathrm{P}$ mediated GSH depletion in INS-1E pancreatic cells. Treatment with RES + B(a)P significantly increased the level of GSH compared with treatment with B(a)P alone. It is possible that RES attenuates B(a)P-mediated depletion of GSH levels by increasing the biosynthesis of GSH and also by scavenging B(a)P-induced ROS. Polyphenolic compounds with hydroxyl groups at 4' and 5 positions, as seen in resveratrol, have the potential to scavenge free radicals [62] [63]. Our data corroborate previous observations of the ability of RES to scavenge free radicals such as $\mathrm{OH}$ and $\mathrm{O}_{2}^{--}$[33] and have been shown to possess the antioxidant property [64].

The tumor suppressor p53, a transcription factor that is activated by various forms of cellular stress, was one of the earliest detected cancer gene [65]. Sin et al. [65] reported the increased levels of p53 protein in rats treated with the combination of RES, and sirtinol which is a Sirt-1 inhibitor. In this context, the combination consisting of RES and sirtinol can be used for preventing the harmful effects of B(a)P. In our study, although RES was used alone, expression levels of p53 in RES group and $\mathrm{B}(\mathrm{a}) \mathrm{P}+$ RES group were increased by 2.07- and by 1.60 -fold compared to the control and $\mathrm{B}(\mathrm{a}) \mathrm{P}$ group, respectively. Therefore, it can be said that apoptosis is stimulated via p 53 mediated mechanism reported by 
Soengas et al. [66], by RES in this study. The role of RES in the induction of apoptosis in various cells is controversial. The agent has been shown to induce apoptosis in cancer cells, such as skin cancer cells [67], and has been shown to play a protective role against apoptosis in human tenocytes [68], endothelial cells [69] and other cell types, particularly under oxidative stress [70]. And in this study, we confirmed the therapeutic role of RES against the reduced-apoptosis in INS-1 pancreatic cells exposure to B(a)P.

It has been reported that RES has anti-diabetic effects in different in vivo and in vitro studies [71] [72]. Xie et al. [72] showed that RES could induce the expression of several $\beta$-cell genes including insulin gene. Animal studies have shown similar beneficial effects of RES by increasing insulin secretion [73] or enhancing sensitivity to insulin in peripheral organs via activation of Sirt-1 [74]. In our study, RES increased the levels of Ins-1 and Ins- 2 genes by 2.03- and 1.63-folds respectively, in RES $+\mathrm{B}(\mathrm{a}) \mathrm{P}$ group compared to the $\mathrm{B}(\mathrm{a}) \mathrm{P}$ group. In addition, insulin hormone secretion was significantly increasing in RES + B(a)P group compared with $\mathrm{B}(\mathrm{a}) \mathrm{P}$ group in this study. It has been suggested that these results are consistent with the results of previous studies mentioned above.

On the other hand, it was shown that RES increased the expression of key $\beta$-cell transcription factors such as Foxo1 and Ngn3 [72]. The increased expression of FoxO1 by resveratrol treatment in this study explains and supports the positive effect of RES on insulin levels.

The expression of the Bcl-2 gene has been reported to be significantly suppressed in the cerebral cortex of rats exposed to $\mathrm{B}(\mathrm{a}) \mathrm{P}$. This effect of $\mathrm{B}(\mathrm{a}) \mathrm{P}$ was attributed its enhancing effect on apoptosis index [74]. In consistent with the literature, expression of Bcl-2 gene was suppressed by 1.15 fold in the $\mathrm{B}(\mathrm{a}) \mathrm{P}$ group in this study.

He et al. [75] applied RES as an activator for SIRT1 for preventing the effects of apoptosis induced by $\mathrm{H}_{2} \mathrm{O}_{2}$ in mouse osteoblastic cells MC3T3-E1 cell lines. With $\mathrm{H}_{2} \mathrm{O}_{2}$ administration, p53, bax and caspase-9 were stimulated while SIRT1 and Bcl-2 were inhibited. It was determined that RES stimulated the activity of both Bcl-2 and SIRT1 genes against this effect of $\mathrm{H}_{2} \mathrm{O}_{2}$ [75]. Similarly, RES increased the level of Bcl-2 expression in this study. This increase was also assumed to be effective in removing the reduction in Bcl-2 gene expression caused by $\mathrm{B}(\mathrm{a}) \mathrm{P}$.

\section{Conclusion}

The harmful effects of $\mathrm{B}(\mathrm{a}) \mathrm{P}$ on beta cells of pancreas and therapeutic aspects of RES have been investigated for the first time in this study. For this reason, it is believed that the results obtained here may contribute to the literature. Based on all these results, it can be said that RES may be a very important therapeutic agent in the protection or treatment of adverse effects of carcinogenesis and oxidative changes that may occur due to $\mathrm{B}(\mathrm{a}) \mathrm{P}$ toxication in pancreatic beta cells. The demonstration of these effects of RES reveals how important RES is in 
preventing the harmful effects of environmental pollutants. The importance of RES-rich foods has been once again revealed by scientific evidence. With further studies, it may be possible to illuminate the cellular or molecular mechanisms underlying these effects of RES.

\section{Acknowledgements}

This study was supported by the Scientific Research Projects Unit of Afyon Kocatepe University (Project No: 10.TIP.18/MSc Thesis in Medical Biochemistry) and NATO-SPS Program (Project No: MYP-G5266). The author wishes to thank Prof. Dr. Suat Erdoğan (Trakya University, Turkey. Ph.D. in Glasgow) for English revision of the text.

\section{Conflicts of Interest}

The authors declare no conflicts of interest regarding the publication of this paper.

\section{References}

[1] Dodds, S. (2017) The How-To for Type 2: An Overview of Diagnosis and Management of Type 2 Diabetes Mellitus. Nursing Clinics of North America, 52, 513-522.

https://doi.org/10.1016/j.cnur.2017.07.002

[2] Felton, A.M., LaSalle, J. and McGill, M. (2016) Global Partnership for Effective Diabetes Management. Treatment Urgency: The Importance of Getting People with Type 2 Diabetes to Target Promptly. Diabetes Research and Clinical Practice, 117, 100-103. https://doi.org/10.1016/j.diabres.2016.04.026

[3] Sazlina, S.G., Mastura, I., Ahmad, Z., Cheong, A.T., Adam, B.M., Jamaiyah, H., Lee, P.Y., Syed-Alwi, S.A., Chew, B.H. and Sriwahyu, T. (2014) Control of Glycemia and Other Cardiovascular Disease Risk Factors in Older Adults with Type 2 Diabetes Mellitus: Data from the Adult Diabetes Control and Management. Geriatrics \& Gerontology International, 14, 130-137. https://doi.org/10.1111/ggi.12070

[4] Lee, E., Ryu, G.R., Ko, S.H., Ahn, Y.B. and Song, K.H. (2017) A Role of Pancreatic Stellate Cells in Islet Fibrosis and $\beta$-Cell Dysfunction in Type 2 Diabetes Mellitus. Biochemical and Biophysical Research Communications, 485, 328-334. https://doi.org/10.1016/j.bbrc.2017.02.082

[5] Butler, A.E., Janson, J., Bonner-Weir, S., Ritzel, R., Rizza, R.A. and Butler, P.C. (2003) Beta-Cell Deficit and Increased Beta-Cell Apoptosis in Humans with T2DM. Diabetes, 52, 102-110. https://doi.org/10.2337/diabetes.52.1.102

[6] Kesavulu, M.M., Rao, B.K., Giri, R., Vijaya, J., Subramanyam, G. and Apparao, C. (2001) Lipid Peroxidation and Antioxidant Enzyme Status in Type 2 Diabetics with Coronary Heart Disease. Diabetes Research and Clinical Practice, 53, 33-39. https://doi.org/10.1016/S0168-8227(01)00238-8

[7] Bhor, V.M., Raghuram, N. and Sivakami, S. (2004) Oxidative Damage and Altered Antioxidant Enzyme Activities in the Small Intestine of Streptozotocin-Induced Diabetic Rats. The International Journal of Biochemistry \& Cell Biology, 36, 89-97. https://doi.org/10.1016/S1357-2725(03)00142-0

[8] Ozsoy-Sacan, O., Karabulut-Bulan, O., Bolkent, S., Yanardag, R. and Ozgey, Y. (2004) Effects of Chard (Beta vulgaris L. var cicla) on the Liver of the Diabetic Rats: A Morphological and Biochemical Study. Bioscience, Biotechnology, and Bioche- 
mistry, 68, 1640-1648. https://doi.org/10.1271/bbb.68.1640

[9] Venkateswaran, S. and Pari, L. (2003) Effect of Coccinia indica Leaf Extract on Plasma Antioxidants in Streptozotocin-Induced Experimental Diabetes in Rats. Phytotherapy Research, 17, 605-608. https://doi.org/10.1002/ptr.1195

[10] Eizirik, D.L. and Poulsen, T.M. (2001) A Choice of Death-The Signal-Transduction of Immune-Mediated Beta Cell Apoptosis. Diabetologia, 44, 2115-2133. https://doi.org/10.1007/s001250100021

[11] Mathis, D., Vence, L. and Benoist, C. (2001) Beta-Cell Death during Progression to Diabetes. Nature, 414, 792-798. https://doi.org/10.1038/414792a

[12] Kaneto, H., Kajimoto, Y., Miyagawa, J., Matsuoka, T., Fujitani, Y., Umayahara, Y., Hanafusa, T., Matsuzawa, Y., Yamasaki, Y. and Hori, M. (1999) Beneficial Effects of Antioxidants in Diabetes: Possible Protection of Pancreatic Beta-Cells against Glucose Toxicity. Diabetes, 48, 2398-2406. https://doi.org/10.2337/diabetes.48.12.2398

[13] Oyadomari, S., Takeda, K., Takiguchi, M., Gotoh, T., Matsumoto, M., Wada, I., Akira, S., Araki, E. and Mori, M. (2001) Nitric Oxide-Induced Apoptosis in Pancreatic Beta Cells Is Mediated by the Endoplasmic Reticulum Stress Pathway. Proceedings of the National Academy of Sciences of the United States of America, 98, 10845-10850. https://doi.org/10.1073/pnas.191207498

[14] Saini, K.S., Thompson, C., Winterford, C.M., Walker, N.I. and Cameron, D.P. (1996) Streptozotocin at Low Doses Induces Apoptosis and at High Doses Causes Necrosis in a Murine Pancreatic Beta Cell Line, INS-1. Biochemistry and Molecular Biology International, 39, 1229-1236. https://doi.org/10.1080/15216549600201422

[15] Unger, R.H. (2002) Lipotoxic Diseases. Annual Review of Medicine, 53, 319-336. https://doi.org/10.1146/annurev.med.53.082901.104057

[16] Withers, D.J., Burks, D.J., Towery, H.H., Altamuro, S.L., Flint, C.L. and White, M.F. (1999) Irs-2 Coordinates Igf-1 Receptor-Mediated Beta-Cell Development and Peripheral Insulin Signalling. Nature Genetics, 23, 32-40.

https://doi.org/10.1038/12631

[17] Longnecker, M.P. and Daniels, J.L. (2001) Environmental Contaminants as Etiologic Factors for Diabetes. Environmental Health Perspectives, 109, 871-876. https://doi.org/10.1289/ehp.01109s6871

[18] Henriksen, G.L., Ketchum, N.S., Michalek, J.E. and Swaby, J.A. (1997) Serum Dioxin and Diabetes Mellitus in Veterans of Operation Ranch Hand. Epidemiology, 8, 252-825. https://doi.org/10.1097/00001648-199705000-00005

[19] Bertazzi, P.A., Consonni, D., Bachetti, S., Rubagotti, M., Baccerelli, A., Zocchetti, C. and Pesatori, A.C. (2001) Health Effects of Dioxin Exposure: A 20-Year Mortality Study. American Journal of Epidemiology, 153, 1031-1044. https://doi.org/10.1093/aje/153.11.1031

[20] Steenland, K., Calvert, G., Ketchum, N. and Michalek, J. (2001) Dioxin and Diabetes Mellitus: An Analysis of the Combined NIOSH and Ranch Hand Data. Occupational and Environmental Medicine, 58, 641-648. https://doi.org/10.1136/oem.58.10.641

[21] Vasiliu, O., Cameron, L., Gardiner, J., Deguire, P. and Karmaus, W. (2006) Polybrominated Biphenyls, Polychlorinated Biphenyls, Body Weight, and Incidence of Adult Onset Diabetes Mellitus. Epidemiology, 17, 352-359. https://doi.org/10.1097/01.ede.0000220553.84350.c5

[22] Aygün, S.F. and Kabadayi, F. (2005) Determination of Benzo[a]pyrene in Charcoal Grilled Meat Samples by HPLC with Fluorescence Detection. International Journal of Food Sciences and Nutrition, 56, 581-585. https://doi.org/10.1080/09637480500465436 
[23] Gelboin, H.V. (1980) Benzo[alpha]pyrene Metabolism, Activation and Carcinogenesis: Role and Regulation of Mixed-Function Oxidases and Related Enzymes. Physiological Reviews, 60, 1107-1166. https://doi.org/10.1152/physrev.1980.60.4.1107

[24] Kumar, S., Antony, M. and Mehrotra, N.K. (1982) Induction of Benzo[a]pyrene Hydroxylase in Skin and Liver by Cutaneous Application of Jute Batching Oil. Toxicology, 23, 347-352. https://doi.org/10.1016/0300-483X(82)90072-5

[25] Chen, Z., Jin, K., Gao, L., Lou, G., Jin, Y., Yu, Y. and Lou, Y. (2010) Anti-Tumor Effects of Bakuchiol, an Analogue of Resveratrol, on Human Lung Adenocarcinoma A549 Cell Line. European Journal of Pharmacology, 25, 170-179. https://doi.org/10.1016/j.ejphar.2010.06.025

[26] Bae, S., Lee, E.M., Cha, H.J., Kim, K., Yoon, Y., Lee, H., et al. (2011) Resveratrol Alters microRNA Expression Profiles in A549 Human Non-Small Cell Lung Cancer Cells. Molecules and Cells, 32, 243-249. https://doi.org/10.1007/s10059-011-1037-z

[27] Zhang, W., Wang, X. and Chen, T. (2011) Resveratrol Induces Mitochondria-Mediated AIF and to a Lesser Extent Caspase-9-Dependent Apoptosis in $\mathrm{Hu}$ man Lung Adenocarcinoma ASTC-a-1 Cells. Molecular and Cellular Biochemistry, 354, 29-37. https://doi.org/10.1007/s11010-011-0802-9

[28] Vetterli, L., Brun, T., Giovannoni, L., Bosco, D. and Maechler, P. (2011) Resveratrol Potentiates Glucose-Stimulated Insulin Secretion in INS-1E Beta-Cells and Human Islets through a SIRT1-Dependent Mechanism. The Journal of Biological Chemistry, 286, 6049-6060. https://doi.org/10.1074/jbc.M110.176842

[29] Picard, F., Kurtev, M., Chung, N., Topark-Ngarm, A., Senawong, T., Machado, D.E., et al. (2004) Sirt1 Promotes Fat Mobilization in White Adipocytes by Repressing PPAR-Gamma. Nature, 429, 771-776. https://doi.org/10.1038/nature02583

[30] Bordone, L., Motta, M.C., Picard, F., Robinson, A., Jhala, U.S., Apfeld, J., et al. (2006) Sirt1 Regulates Insulin Secretion by Repressing UCP2 in Pancreatic Beta Cells. PLOS Biology, 4, e31. https://doi.org/10.1371/journal.pbio.0040031

[31] Ramsey, K.M., Mills, K.F., Satoh, A. and Imai, S. (2008) Age-Associated Loss of Sirt1 Mediated Enhancement of Glucose-Stimulated Insulin Secretion in Beta Cell-Specific Sirt1-Overexpressing (BESTO) Mice. Aging Cell, 7, 78-88. https://doi.org/10.1111/j.1474-9726.2007.00355.x

[32] Wu, L., Zhou, L., Lu, Y., Zhang, J., Jian, F., Liu, Y., et al. (2012) Activation of SIRT1 Protects Pancreatic $\beta$-Cells against Palmitate-Induced Dysfunction. Biochimica et Biophysica Acta, 1822, 1815-1825. https://doi.org/10.1016/j.bbadis.2012.08.009

[33] Kode, A., Rajendrasozhan, S., Caito, S., Yang, S.R., Megson, I.L. and Rahman, I. (2008) Resveratrol Induces Glutathione Synthesis by Activation of Nrf2 and Protects against Cigarette Smoke-Mediated Oxidative Stress in Human Lung Epithelial Cells. The American Journal of Physiology_Lung Cellular and Molecular Physiology, 294, 478-488. https://doi.org/10.1152/ajplung.00361.2007

[34] Tampioa, M., Loikkanena, J., Myllynenb, P., Mertanena, A. and Vahakangasa, K.H. (2008) Benzo(a)pyrene Increases Phosphorylation of p53 at Serine 392 in Relation to p53 Induction and Cell Death in MCF-7 Cells. Toxicology Letters, 178, 152-159. https://doi.org/10.1016/j.toxlet.2008.03.006

[35] Bradford, M.M. (1976) A Rapid and Sensitive Method for the Quantitation of Microgram Quantities of Protein Utilizing the Principle of Protein-Dye Binding. Analytical Biochemistry, 72, 248-254. https://doi.org/10.1016/0003-2697(76)90527-3

[36] Erel, O. (2004) A Novel Automated Method to Measure Total Antioxidant Response against Potent Free Radical Reactions. Clinical Biochemistry, 37, 112-119. https://doi.org/10.12691/jfnr-2-8-1 
[37] Erel, O. (2005) A New Automated Colorimetric Method for Measuring Total Oxidant Status. Clinical Biochemistry, 38, 1103-1111. https://doi.org/10.1016/j.clinbiochem.2005.08.008

[38] Esen, C., Alkan, B.A., Kırnap, M., Akgül, O., Işıkoğlu, S. and Erel, O. (2012) The Effects of Chronic Periodontitis and Rheumatoid Arthritis on Serum and Gingival Crevicular Fluid Total Antioxidant/Oxidant Status and Oxidative Stress Index. Journal of Periodontology, 83, 773-779. https://doi.org/10.1902/jop.2011.110420

[39] Green, L.C., Wagner, D.A., Glogowski, J., Skipper, P.L., Wishnok, J.S. and Tannenbaum, S.R. (1982) Analysis of Nitrate, Nitrite, and [15N]nitrate in Biological Fluids. Analytical Biochemistry, 126, 131-138. https://doi.org/10.1016/0003-2697(82)90118-X

[40] Buetler, E., Dubon, O. and Kelly, B.M. (1963) Improved Method for the Determination of Blood Glutathione. Journal of Laboratory and Clinical Medicine, 61, 882-888.

[41] Pfaffl, M.W. (2001) A New Mathematical Model for Relative Quantification in Real-Time RT-PCR. Nucleic Acids Research, 29, e45. https://doi.org/10.1093/nar/29.9.e45

[42] Tafeeva, E.A., Ivanov, A.V., Titova, A.A. and Akhmetzianova, I.F. (2015) Air Pollutions as a Risk Factor for the Population Health in Kazan City. Gigiena i Sanitariia, 94, 37-40.

[43] Esposito, K., Petrizzo, M., Maiorino, M.I., Bellastella, G. and Giugliano, D. (2016) Particulate Matter Pollutants and Risk of T2DM: A Time for Concern? Endocrine, 51, 32-37. https://doi.org/10.1007/s12020-015-0638-2

[44] Sundaresan, M., Yu, Z.X., Ferrans, V.J., Irani, K. and Finkel, T. (1995) Requirement for Generation of $\mathrm{H}_{2} \mathrm{O}_{2}$ for Platelet-Derived Growth Factor Signal Transduction. Science, 270, 296-299. https://doi.org/10.1126/science.270.5234.296

[45] Rajendran, P., Venogopal, R., Ekambaram, G., Aadithya, A. and Sakthisekaran, D. (2008) Rehabilitating Activity of Mangiferin in Benzo(a)pyrene Induced Lung Carcinogenesis. Asian Journal of Biochemistry, 3, 118-125. https://doi.org/10.3923/ajb.2008.118.125

[46] Aksoy, Y. (2002) The Role of Glutathione in Antioxidant Mechanism. Turkiye Klinikleri Journal of Medical Sciences, 22, 442-448. https://doi.org/10.1016/S0737-0806(02)70162-7

[47] Liu, Y., Wu, Y.M. and Zhang, P.Y. (2015) Protective Effects of Curcumin and Quercetin during Benzo(a)pyrene Induced Lung Carcinogenesis in Mice. European Review for Medical and Pharmacological Sciences, 19, 1736-1743.

[48] Sakr, H.F., Abbas, A.M., Elsamanoudy, A.Z. and Ghoneim, F.M. (2015) Effect of Fluoxetine and Resveratrol on Testicular Functions and Oxidative Stress in a Rat Model of Chronic Mild Stress-Induced Depression. Journal of Physiology and Pharmacology, 66, 515-527.

[49] Spanier, G., Xu, H., Xia, N., Tobias, S., Deng, S., Wojnowski, L., et al. (2009) Resveratrol Reduces Endothelial Oxidative Stress by Modulating the Gene Expression of Superoxide Dismutase 1 (SOD1), Glutathione Peroxidase 1 (GPx1) and NADPH Oxidase Subunit (Nox4). Journal of Physiology and Pharmacology, 60, 111-116.

[50] Vardi, N., Parlakpınar, H., Ates, B., Cetin, A. and Otlu, A. (2009) Antiapoptotic and Antioxidant Effects of $\beta$-Carotene against Methotrexate-Induced Testicular Injury. Fertility and Sterility, 92, 2028-2033. https://doi.org/10.1016/j.fertnstert.2008.09.015

[51] Frankel, E.N., Waterhouse, A.L. and Kinsella, J.E. (1993) Inhibition of Human LDL Oxidation by Resveratrol. The Lancet, 341, 1103-1104. 
https://doi.org/10.1016/0140-6736(93)92472-6

[52] Wang, Q., Xu, J., Rottinghaus, G.E., Simonyi, A., Lubahn, D., Sun, G.Y. and Sun, A.Y. (2002) Resveratrol Protects against Global Cerebral Ischemic Injury in Gerbils. Brain Research, 958, 439-947. https://doi.org/10.1016/S0006-8993(02)03543-6

[53] Giovannini, L., Migliori, M., Longoni, B.M., Das, D.K., Bertelli, A.A., Panichi, V., et al. (2001) Resveratrol, a Polyphenol Found in Wine, Reduces Ischemia Reperfusion Injury in Rat Kidneys. Journal of Cardiovascular Pharmacology, 37, 262-270. https://doi.org/10.1097/00005344-200103000-00004

[54] Kim, J.K., Fillmore, J.J., Sunshine, M.J., Albrecht, B., Higashimori, T., Kim, D.W., et al. (2004) PKCtheta Knockout Mice Are Protected from Fat-Induced Insulin Resistance. Journal of Clinical Investigation, 114, 823-827. https://doi.org/10.1172/JCI200422230

[55] Cai, D., Yuan, M., Frantz, D.F., Melendez, P.A., Hansen, L., Lee, J., et al. (2005) Local and Systemic Insulin Resistance Resulting from Hepatic Activation of IKK-Beta and NF-kappaB. Nature Medicine, 11, 183-190. https://doi.org/10.1038/nm1166

[56] Kong, W., Chen, L.L., Zheng, J., Zhang, H.H., Hu, X., Zeng, T.S., et al. (2015) Resveratrol Supplementation Restores High-Fat Diet-Induced Insulin Secretion Dysfunction by Increasing Mitochondrial Function in Islet. Experimental Biology and Medicine (Maywood), 240, 220-229. https://doi.org/10.1177/1535370214548998

[57] Moynihan, K.A., Plueger, M.M., Bernal-Mizrachi, E., Ford, E., Cras-Meneur, C., Permutt, M.A., et al. (2005) Increased Dosage of Mammalian Sir2 in Pancreatic Beta Cells Enhances Glucose-Stimulated Insulin Secretion in Mice. Cell Metabolism, 2, 105-117. https://doi.org/10.1016/j.cmet.2005.07.001

[58] Liu, Z., Jiang, C., Zhang, J., Liu, B. and Du, Q. (2016) Resveratrol Inhibits Inflammation and Ameliorates Insulin Resistant Endothelial Dysfunction via Regulation of AMP-Activated Protein Kinase and Sirtuin 1 Activities. Journal of Diabetes, 8 , 324-335. https://doi.org/10.1111/1753-0407.12296

[59] Rotruck, J.T., Pope, A.L., Ganther, H.E. and Hoekstra, W.G. (1972) Prevention of Oxidative Damage to Rat Erythrocytes by Dietary Selenium. The Journal of Nutrition, 102, 689-696. https://doi.org/10.1093/jn/102.5.689

[60] Rotruck, J.T., Pope, A.L., Ganther, H.E., Swanson, A.B., Hafeman, D.G. and Hoekstra, W.G. (1973) Selenium: Biochemical Role as a Component of Glutathione Peroxidase. Science, 179, 588-590. https://doi.org/10.1126/science.179.4073.588

[61] Kawada, N., Seki, S., Inoue, M. and Kuroki, T. (1998) Effect of Antioxidants, Resveratrol, Quercetin, and N-Acetylcysteine, on the Functions of Cultured Rat Hepatic Stellate Cells and Kupffer Cells. Hepatology, 27, 1265-1274.

https://doi.org/10.1002/hep.510270512

[62] Fauconneau, B., Waffo-Teguo, P., Huguet, F., Barrier, L., Decendit, A. and Merillon, J.M. (1997) Comparative Study of Radical Scavenger and Antioxidant Properties of Phenolic Compounds from Vitis vinifera Cell Cultures Using in Vitro Tests. Life Sciences, 61, 2103-2110. https://doi.org/10.1016/S0024-3205(97)00883-7

[63] Teissedre, P.L., Frankel, E.N., Waterhouse, A.L., Peleg, H. and German, J.B. (1996) Inhibition of in Vitro Human LDL Oxidation by Phenolic Antioxidants from Grapes and Wines. Journal of the Science of Food and Agriculture, 70, 55-61. https://doi.org/10.1002/(SICI)1097-0010(199601)70:1<55::AID-JSFA471>3.3.CO;2-O

[64] Brito, P.M., Mariano, A., Almeida, L.M. and Dinis, T.C. (2006) Resveratrol Affords Protection against Peroxynitrite-Mediated Endothelial Cell Death: A Role for Intracellular Glutathione. Chemico-Biological Interactions, 164, 157-166. https://doi.org/10.1016/j.cbi.2006.09.007 
[65] Sin, T.K., Yung, B.Y., Yip, S.P., Chan, L.W., Wong, C.S., Tam, E.W., et al. (2015) SIRT1-Dependent Myoprotective Effects of Resveratrol on Muscle Injury Induced by Compression. Frontiers in Physiology, 6, 293. https://doi.org/10.3389/fphys.2015.00293

[66] Soengas, M.S., Alarcón, R.M., Yoshida, H., Giaccia, A.J., Hakem, R., Mak, T.W. and Lowe, S.W. (1999) Apaf-1 and Caspase-9 in p53-Dependent Apoptosis and Tumor Inhibition. Science, 284, 156-159. https://doi.org/10.1126/science.284.5411.156

[67] Dun, J., Chen, X., Gao, H., Zhang, Y., Zhang, H. and Zhang, Y. (2015) Resveratrol Synergistically Augments Anti-Tumor Effect of 5-FU in Vitro and in Vivo by Increasing S-Phase Arrest and Tumor Apoptosis. Experimental Biology and Medicine (Maywood), 240, 1672-1681. https://doi.org/10.1177/1535370215573396

[68] Busch, F., Mobasheri, A., Shayan, P., Stahlmann, R. and Shakibaei, M. (2012) Sirt-1 Is Required for the Inhibition of Apoptosis and Inflammatory Responses in Human Tenocytes. The Journal of Biological Chemistry, 287, 25770-25781. https://doi.org/10.1074/jbc.M112.355420

[69] Csiszár, A., Csiszar, A., Pinto, J.T., Gautam, T., Kleusch, C., Hoffmann, B. and Tucsek, Z. (2015) Resveratrol Encapsulated in Novel Fusogenic Liposomes Activates Nrf2 and Attenuates Oxidative Stress in Cerebromicrovascular Endothelial Cells from Aged Rats. The Journals of Gerontology. Series A, Biological Sciences and Medical Sciences, 70, 303-313. https://doi.org/10.1093/gerona/glu029

[70] Chan, C.M., Huang, C.H., Li, H.J., Hsiao, C.Y., Su, C.C., Lee, P.L. and Hung, C.F. (2015) Protective Effects of Resveratrol against UVA-Induced Damage in ARPE19 Cells. International Journal of Molecular Sciences, 16, 5789-5802. https://doi.org/10.3390/ijms16035789

[71] Timmers, S., Hesselink, M.K. and Schrauwen, P. (2013) Therapeutic Potential of Resveratrol in Obesity and T2DM: New Avenues for Health Benefits? Annals of the New York Academy of Sciences, 3, 83-89. https://doi.org/10.1111/nyas.12185

[72] Xie, S., Sinha, R.A., Singh, B.K., Li, G.D., Han, W. and Yen, P.M. (2013) Resveratrol Induces Insulin Gene Expression in Mouse Pancreatic $\alpha$-Cells. Cell \& Bioscience, 13, 47. https://doi.org/10.1186/2045-3701-3-47

[73] Szkudelski, T. and Szkudelska, K. (2011) Anti-Diabetic Effects of Resveratrol. Annals of the New York Academy of Sciences, 3, 34-39. https://doi.org/10.1111/j.1749-6632.2010.05844.x

[74] Gertz, M., Nguyen, G.T., Fischer, F., Suenkel, B., Schlicker, C., Franzel, B., et al. (2012) A Molecular Mechanism for Direct Sirtuin Activation by Resveratrol. PLoS ONE, 3, e49761. https://doi.org/10.1371/journal.pone.0049761

[75] He, N., Zhu, X., He, W., Zhao, S., Zhao, W. and Zhu, C. (2015) Resveratrol Inhibits the Hydrogen Dioxide-Induced Apoptosis via Sirt 1 Activation in Osteoblast Cells. Bioscience, Biotechnology, and Biochemistry, 79, 1779-1186.

https://doi.org/10.1080/09168451.2015.1062712 